\title{
Faecal contamination in groundwater and its association with population density: a study in coastal areas of Semarang
}

\author{
Dina Rahayuning Pangestuti ${ }^{1 *}$, Thomas Triadi Putranto ${ }^{2}$, Novie Susanto ${ }^{3}$ \\ ${ }^{1}$ Public Health Department, Faculty of Public Health, Diponegoro University, Semarang 50275, \\ Indonesia \\ ${ }^{2}$ Geological Engineering Department, Faculty of Technic, Diponegoro University, Semarang 50275, \\ Indonesia \\ ${ }^{3}$ Industrial Engineering Department, Faculty of Technic, Diponegoro University, Semarang 50275, \\ Indonesia
}

\begin{abstract}
Increased population density causes the supply of clean water to be unable to meet the requirements. The coastal area of Semarang is also faced with a tidal problem. While good sanitation is a top priority in improving health, nutrition and productivity ( $6^{\text {th }}$ SDG target), the cause of water borne disease must be considered. This research was conducted in May 2019 at 30 points in the coastal area of Semarang, covering 9 subdistricts. Assessment of microbiology is carried out on coliform parameters and the presence of Eschericia coli. Data on septic tank type, depth, distance of the septic tank to the sample points and drainage frequency were collected. Population data are based on data from BPS. Hydrogeological mapping was used to describe the distribution of faecal contamination and other factors. Around $73.3 \%$ of the groundwater samples exceeded the coliform parameter limit and $86.7 \%$ of the samples were found to have E. coli. Only $37.5 \%$ of the septic tank is cemented and $66.7 \%$ with a safe distance from the water source. Population density was not significantly related to poor groundwater quality, because even though the area is less densely populated, E. coli is found positive in ground water.
\end{abstract}

\section{Introduction}

Water-borne diseases remain one of the major health problems in the world, especially in developing countries. Most diarrheal diseases come from water and poor sanitation. Safely managed sanitation is a top priority for improving people's health, nutrition and productivity, and this is a target for the sixth Sustainable Development Goal (SDG).

Therefore, achieving the 6th SDG requires a more sensitive strategy to reach Indonesian children and families with better access to safe and clean water supplies. According to BPS, the percentage of households that have access to safe and sustainable drinking water services increased from 2015 to 2018 by $6.32 \%$ to $73.3 \%$, above the national average

* Corresponding author: dinapangestuti@lecturer.undip.ac.id 
increase. Potable drinking water is defined as drinking water with a minimum distance of 10 meter from the final disposal site which is sourced from plumbing pipes, drilled wells / pumps, protected wells, protected springs, including rainwater[1]. However, this percentage will decrease if the water source which is really safe to be a consideration. Improved water quality control strategies, together with increased hygiene of sewage, can be expected to provide significant health benefits[2].

Groundwater is water that is contained below the surface in the soil and rocks, accumulating in aquifers. It comes from rain water that wet the mountain slopes or the surface of the earth which is then absorbed into the pores of the soil which then flows underground. As part of the hydrological cycle, it flows again to the sea or the surface of the earth and then evaporates and rises into the atmosphere and then falls again to the surface of the earth and so on. Groundwater is the freshest water globally and is an important source of drinking water for the population. In many parts of the world, groundwater sources are the single most important supply for drinking water production, especially in areas with limited or polluted surface water sources. Groundwater based on its location consists of shallow ground water and deep ground water. Deep ground water usually has a more stable quality and a better quality of microbes than surface water. Shallow ground water often requires less advanced processing to be used than surface water. Thus, it is very important that the quality of ground water is protected[2].

Escherichia coli is a dominant member of facultative anaerobic bacteria derived from the normal flora of the human colon. The only natural habitat for bacteria is the large intestine in warm-blooded animals. Generally, these bacteria do not survive well outside the intestinal tract, except for E. coli. Its presence in environmental, food or water samples usually indicates faecal contamination, or poor sanitation practices in food processing facilities. E. coli is widely used as an indicator organism to identify food and water samples that may contain an unacceptable level of faecal contamination[3]. Therefore, in the national standard for clean water the coliform number is allowed within the maximum limit of $50 \mathrm{CFU} / 100 \mathrm{ml}$, while the E. coli bacteria has zero tolerance[4].

The problem of clean water quality in the coastal areas of the city of Semarang has been studied for almost 20 years, but the situation is still concerning. Research in North Semarang found that frequent tides in the Bandarharjo and Tanjung Emas areas were significantly correlated with environmental sanitation conditions. About $92.24 \%$ of households used ground water for their main water source. Tidal inundation flooding can contaminate drinking water through seepage from household sewage, livestock waste, or pollution from river flows. The study also found that more than half of the samples contained E. coli. The impact that can arise is the transmission of water-borne diseases, such as diarrhea[5]. Intervention with the Water Safety Plans program has been proven to reduce the percentage of clean water sources of poor quality residents[6]. However, the sustainability of clean water drainage has not been evaluated.

Based on research conducted in the North Semarang area, this study seeks to describe the condition of faecal contamination in the coastal area of the city of Semarang. The study of the relationship between sanitation and population density in developing countries found that there was a significant relationship between the two. The interaction between sanitation and population density has an impact on infants' health. The combination of high population density and poor sanitation threatens the health of infants early in life. However, high density without poor sanitation can substantially reduce health risks, especially infants[7]. Given that Semarang is an area with population density is in the moderate $(43.75 \%)$ and high $(31.25 \%)$ category[8], so a study of the impact on sanitation facilities needs to be done. 


\section{Methods}

This research was conducted in May 2019 at 30 points in the coastal areas of Semarang, namely the districts of Tugu, Ngaliyan, West Semarang, Gajahmungkur, East Semarang, Central Semarang, Pedurungan, Genuk, and Gayamsari. Samples in the form of shallow ground water were taken from dug wells using sterile dark glass bottles and carried out with aseptic. The collected samples were put in ice boxes to keep the temperature low before being examined in the laboratory. Microbiological examination was performed on the total coliform parameters of the MPN method[4, 9] and the presence of qualitative Eschericia coli with selective agar media (Mac-Conkey Agar). This agar is used for the isolation of coliform bacteria, especially E. coli, from various materials. Bile salts and violet crystals inhibit the growth of Gram-positive bacteria. The appearance of lactose and red neutral shows the growth of lactose-positive colonies, namely E. coli[10]. Data on the type of septic tank, depth, distance of the septic tank to the dug well and frequency of cleaning[11] were collected. Population data was based on data from BPS, so the population density was expressed in units of number of people per $\mathrm{km}^{2}$. Hydrogeological mapping with field campaign was used to describe the distribution of faecal contamination and other factors[12].

Descriptive data was used to describe percentage and frequency. Bivariate statistical analysis (Chi-square, Fisher Exact test) was used to examine the relationship between variables of the type of septic tank, distance of the septic tank with groundwater sources, population density and the presence of E. coli in the sample. A significance level of 0.05 was used.

\section{Results and Discussions}

Total coliform or specific bacteria in Escherichia coli are often used as an indicator of sanitation because they are intestinal bacteria that inhabit the human digestive tract. The presence of faecal coliform indicates the presence of pathogenic bacteria in the sample. The existence of certain strains can cause moderate to severe levels of gastroenteritis in humans and animals. The detection method for E. coli was fast, sensitive, specific and easier to carry out; therefore, this bacterium is a good indicator for quality of water. However, the lifetime of $E$. coli in water is short, so the positive results actually show new contamination. Thus, continuous monitoring for $E$. coli to determine the bacteriological quality of water needs to be done[3].

The presence of $E$. coli bacteria in the North Semarang area has been studied for a long time, and it is always confirmed that there is faecal contamination in the water source used by most of the population, i.e. shallow ground water in dug wells. Recent research in Bandarharjo and Tanjung Emas showed that the suspected risk factors were frequent tidal impacts, river pollution and poorly managed household and livestock waste.[5] In line with the results, the conditions were also shown at the location of this study. As regulated in the Minister of Health Decree, [4] the maximum total amount of coliform for non-piped water is $50 \mathrm{CFU} / 100 \mathrm{ml}$ sample. Around $73.3 \%$ of the groundwater samples exceeded the coliform limit and qualitatively, $86.7 \%$ of the samples were found to have E. coli.

Floods or tides often become a factor causing contamination of water resources with faecal bacteria, especially in developing countries[3,13-15]. Research on mapping microbiological conditions, especially sanitation indicators, is trying to be illustrated in Semarang coastal area which stretches from Tugu to Genuk sub-district as illustrated in Figure 1. Human waste disposal facilities with clean water source facilities are two things that determine the existence of faecal contamination. A review of research in the Bangladesh area shows that infant health as the most basic health indicator is in fact 
influenced by faecal disposal facilities[16]. The type of septic tank is very influential, besides the distance from their water source.

Table 1. Profile of sampling point and faecal disposal facility information at the study site $(\mathrm{N}=30)$

\begin{tabular}{|c|c|}
\hline Variable & Value \\
\hline $\begin{array}{c}\text { Elevation (meters above sea level) (median, min.- } \\
\text { max.) }\end{array}$ & $12.5(5.0-38.0)$ \\
\hline Depth of dug well (m) (mean, \pm SD) & $8.5 \pm 4.5$ \\
\hline Depth of water table (m) (median, min.-max.) & $1.02(0.1-9.6)$ \\
\hline $\begin{array}{c}\text { Elevation of water table (meters above sea level) } \\
\text { (median, min.-max.) }\end{array}$ & $11.74(1.7-36.2)$ \\
\hline $\begin{array}{c}\text { Type of septic tank (n, \%) }: \\
\text { Hole pit }\end{array}$ & $4(16.7)$ \\
\hline Soak pit non-cemented & $5(20.8)$ \\
\hline Soak pit cemented & $6(25)$ \\
\hline Septic tank cemented & $9(37.5)$ \\
\hline Depth of tank (m) (median, min.-max.) & $3.0(0-6.0)$ \\
\hline Distance of tank with dug well (mean, \pm SD)* & $12.7 \pm 5.7$ \\
\hline $\begin{array}{c}\text { Distance of tank with dug well according to } \\
\text { regulation (n, \%): }\end{array}$ & $8(33.3)$ \\
\hline$<10$ m & $16(66.7)$ \\
\hline N=24, 6 data were missing & 9 \\
\hline
\end{tabular}

A systematically review of the type of septic tank on groundwater quality found that faecal contamination can pollute the environment depending also on the environmental context in the region, especially hydrological and soil conditions. Nearly half of the studies in it assess microbial contaminants using an experimental approach. Based on the results of soil sampling at varying distances in more than 50 latrines in wet and dry conditions, with a maximum distance of $5.5 \mathrm{~m}$ from latrines in wet and sandy conditions, E. coli was found. At least in vertical conditions with a distance of $\geq 3-4 \mathrm{~m}$ between the bottom of the hole and the water level will maintain safe groundwater quality. In addition, ease of contamination is also supported by depending on the degree of soil saturation and groundwater flow velocity[17]. At a research site in India marked by shallow water levels and broken rock aquifers, high concentrations of faecal coliforms were found in domestic wells located near pit latrines and septic tanks. During the rainy season, rotaviruses are transported by groundwater flow in the upper part of the ground, whereas travel in the dry season is more likely to be caused by directly contaminated surface water[18]. The same condition is likely to occur in this study. Only $37.5 \%$ of the septic tank is cemented and $66.7 \%$ with a safe distance from the water source (Figure 1). Based on the season, this research was conducted in May, which entered the rainy season even though the rainfall intensity in that month was medium (101-300 mm), so that it could also lead to a high 
chance of spreading faecal contamination in this study. Nevertheless, this study did not compare it with the dry season.

Another factor which can also contribute to the ease of faecal contamination is the level of water table depth. The depth of the ground water surface is the distance between the ground surface and the surface water. The deeper ground water surface in an area shows that the area can absorb water significantly and characterizes the groundwater catchment. Conversely, shallower ground water levels in an area indicate that the area cannot absorb water properly and is identified as a drainage area[12]. Studies found that shallow wells and boreholes and unsafe cement layers from most latrines can contribute to high levels of groundwater pollution[17]. In this study, the depth of the water table is only around 1-10 meters, so the risk of faecal contamination from the environment is very possible (Table 1).

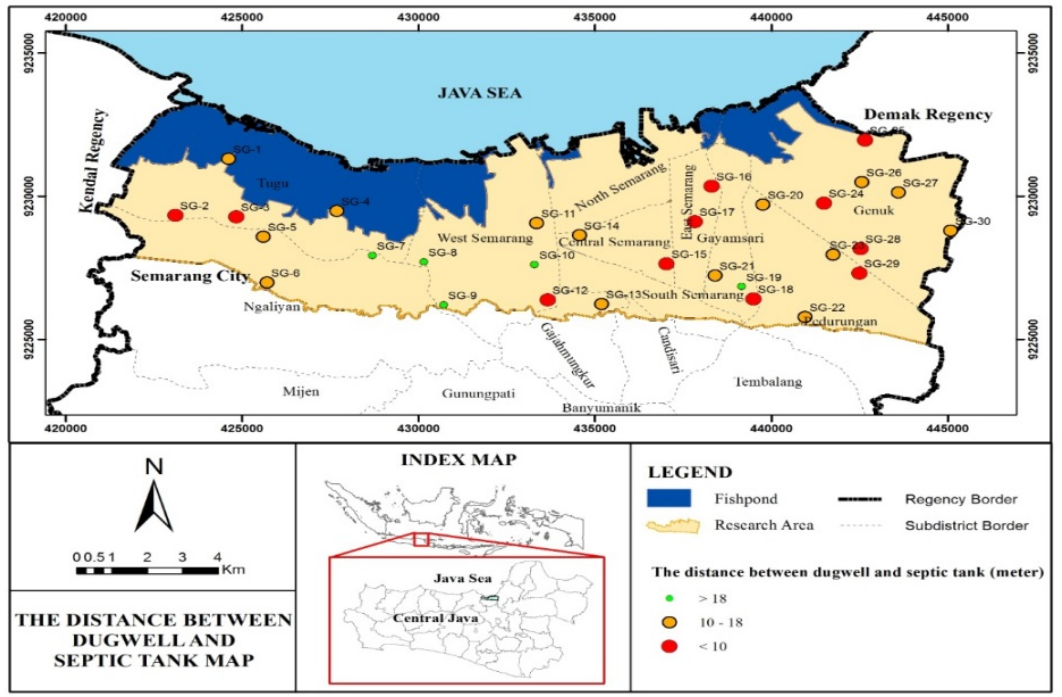

Figure 1. The distribution of the distance between the septic tank and the dug well that was sampled according to regulation[11]

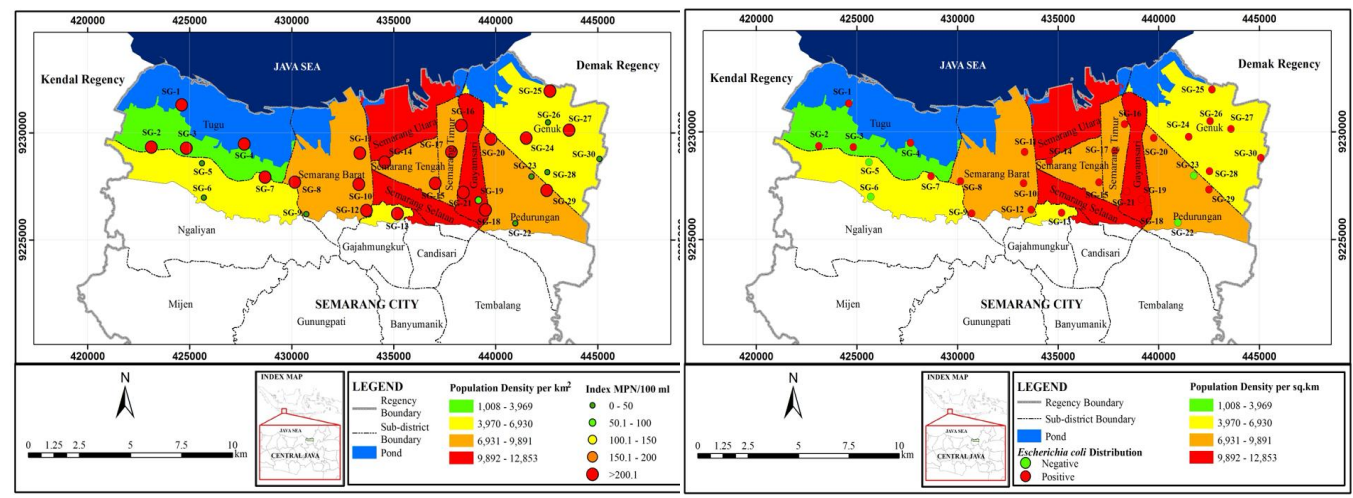

(a)

(b)

Figure 2. Distribution of total coliform (a) and the presence of Eschericia coli in samples (b) according to population density categories 
Based on mapping, the sample point in this study is not only in areas that are known to experience frequent tides and floods. At a point in the area slightly to the south of the Semarang coastal area, it also shows an unsafe distance between groundwater and septic tank (Gajahmungkur, Pedurungan and Gayamsari sub-district areas). However, in average, the distance fulfils the requirement in most samples. This may also be influenced by population density in the region. Figure 2 showed the distribution of highly total coliform and presence of Escherichia coli in almost $90 \%$ of samples in less dense to highly dense population. The presence of E. coli in several studies can also be influenced by population density. In dense settlements, the distance between the septic tank and the dug well will be shorter, thereby increasing the risk of spreading faecal contamination. Research in Uganda found that population density significantly along with rainfall affected the presence of Streptococcus faecal bacteria[15]. However, in this study, population density did not have a positive effect on the presence of $E$. coli $(\mathrm{P}>0.05)$. Samples that exceed safe limits in clean water regulations are significantly related to the presence of $E$. coli ( $\mathrm{P}=0.003$, Fisher's-exact test).

\section{Conclusions}

In health, clean water is a vital factor. Through water sources can cause disease in the presence of bacteria that are not supposed to be in the water, but in the faeces. In general, people use water from shallow ground water. Many factors can affect the quality of clean water from ground water. This study maps the factors that can affect the presence of sanitary indicator bacteria (E. coli). Population density factors based on previous studies can affect clean water quality through intermediary variables, namely the type of septic tank and the distance between the septic tank and the water source. Other factors such as the depth of the groundwater surface and the season together can facilitate the spread of $\mathrm{E}$ coli contamination. This study found that the quality of shallow ground water in the coastal areas of Semarang largely did not meet the requirements. Population density is not significantly associated with poor groundwater quality, because although the area is less densely populated, E. coli was found positive in groundwater.

\section{Acknowledgement}

This research is an International Publication Research program funded with non-government budget funds with agreement number: 474-100 / UN7.6.1 / PP / 2020. Our appreciation goes to Diponegoro University and trained enumerators who help when taking samples in the field, analysis in laboratory and other related parties.

\section{References}

[1] BPS, Percentage of Households That Have Access To Decent And Sustainable Drinking Water Services by Province 2015-2018 (2019)

[2] O. Schmoll, G. Howard, J. Chilton, and I. Chorus, Protecting Groundwater for Health: Managing the Quality of Drinking-water Sources, 1st ed. London: IWA Publishing (2006)

[3] S. T. Odonkor and J. K. Ampofo, Microbiol. Res. (Pavia)., 4, 1, p. 2 (2013)

[4] Kemenkes RI, Peraturan Menteri Kesehatan RI No. 416/MEN.KES/PER/IX/1990. p. 10. (in bahasa) (1990)

[5] Budiyono et al., Procedia Environ. Sci., 23, no. ICTCRED 2014, pp. 93-98 (2015)

[6] Budiyono, G. Praba, S. L. Dian, D. R. Pangestuti, M. Martini, and S. P. Jati, Indian J. Public Heal. Res. Dev., 10, 3, pp. 699-705 (2019)

[7] P. Hathi, S. Haque, L. Pant, D. Coffey, and D. Spears, Demography, 54, 1, pp. 337- 
360 (2017)

[8] E. Setiawan and H. B. Wijaya, J. Pengemb. Kota, 6, 1, p. 1 (in bahasa) (2018)

[9] APHA; AWWA \& WEF, "9221 A-C Multiple-Tube Fermentation Technique for Members of the Coliform Group, 9221D Presence-Absence Coliform Test \& 9221E Fecal Coliform Procedure," (1998)

[10] M. Manafi and B. Kremsmaier, Int. J. Food Microbiol., 71, 2-3, pp. 257-262 (2001)

[11] Standar Nasional Indonesia 2397-2017, “Tata Cara Perencanaan Tangki Septik dengan Pengolahan Lanjutan (Sumur Resapan, Bidang Resapan, Up flow Filter, Kolam Sanita)," Jakarta (2017)

[12] T. T. Putranto, N. Susanto, D. R. Pangestuti, and K. Alexander, IOP Conf. Ser. Earth Environ. Sci., vol. 448, no. 1 (2020)

[13] A. Llopis-González, A. L. Sánchez, P. M. Requena, and M. M. Suárez-Varela, Int. J. Environ. Res. Public Health, vol. 11, no. 5, pp. 5527-5540 (2014)

[14] H. T. Olds, S. R. Corsi, D. K. Dila, K. M. Halmo, M. J. Bootsma, and S. L. McLellan, PLoS Med., vol. 15, no. 7, pp. 1-23 (2018)

[15] G. Howard, S. Pedley, M. Barrett, M. Nalubega, and K. Johal, Water Res., vol. 37, no. 14, pp. 3421-3429 (2003)

[16] P. K. Pandey, P. H. Kass, M. L. Soupir, S. Biswas, and V. P. Singh, AMB Express, vol. 4, no. 1, pp. 1-16 (2014)

[17] J. P. Graham and M. L. Polizzotto, Environ. Health Perspect., vol. 121, no. 5, pp. 521-530 (2013)

[18] B. T. Shivendra and H. K. Ramaraju, Aquat. Procedia, vol. 4, no. Icwrcoe, pp. 1162 1172 (2015)

[19] P. Luo et al., PLoS One, vol. 14, no. 7, pp. 1-17 (2019) 